\title{
Castelporziano, Research and Conservation in a Mediterranean Forest Ecosystem: Presentation of the Volume
}

\author{
Sandro Pignatti $\cdot$ Ernesto Capanna $\cdot$ \\ Enrico Porceddu
}

Received: 12 August 2015/Accepted: 12 August 2015/Published online: 3 September 2015

(C) Accademia Nazionale dei Lincei 2015

The Castelporziano Estate is located in the vicinity of Rome (ca. 20-25 km SW of the town centre; Castle of Castelporziano: $41^{\circ} 44^{\prime} 40^{\prime \prime} \mathrm{N} 12^{\circ} 23^{\prime} 59^{\prime \prime} \mathrm{E}$ ), near the Tiber mouth, and along the coast of the Tyrrhenian Sea: an almost flat surface, from the beach to the interior limit, not exceeding the elevation of a few dozen metres and with a total surface of about $60 \mathrm{~km}^{2}$. Most of the areas included in the Estate are covered with natural or semi-natural vegetation: the area classified as woodland reaches 4.578 ha, i.e. $75.7 \%$ of the total; cultivations, roads and the Castle with surrounding settlements cover a limited surface. Recent investigations show that in Castelporziano about $90 \%$ of the forested areas have maintained their destination use without changes since 1950: presently many of them have the character of old growth forests with monumental trees in need of careful management, in some places

The articles included in this volume, all peer-reviewed, are results of the multidisciplinary project coordinated by the "Accademia

Nazionale delle Scienze detta dei XL”, Rome, Italy, in the area of the Presidential Estate of Castelporziano near Rome.

\section{S. Pignatti $(\square)$}

Dipartimento di Biologia Ambientale, Università di Roma "La Sapienza", Orto Botanico, Largo Cristina di Svezia 24, 00165 Rome, Italy

e-mail: sandro.pignatti@gmail.com

\section{E. Capanna}

Dipartimento di Biologia Animale e dell'Uomo, Università di Roma "La Sapienza", Via Alfonso Borelli 50, 00161 Rome, Italy

e-mail: ernesto.capanna@uniroma1.it

\section{E. Porceddu}

Dipartimento di Agrobiologia e Agrochimica, Università della Tuscia, Via San Camillo de Lellis, 01100 Viterbo, Italy e-mail: porceddu@unitus.it the trunks of dead trees still remain on the ground, and often a diffuse difficulty in rejuvenation is evident. The population of large mammals includes deer and wild boar, together with fallow deer (introduced); roe deer is also present, with few individuals of the endemic Italic variant (2-10 individuals per $\mathrm{km}^{2}$ ). After decades of well-coordinated research, a very high biodiversity was assessed for this area: at present, 5039 species of plants and animals have been recognised, i.e.: Monera 8; Protists 118; Mushrooms 722; Lichens 229; Vascular Plants 1044; Animals 2918 (2380 Insects and 538 others, mainly vertebrates).

It is possible to reconstruct the long history of this territory, based on ancient authors and archaeological evidences. It was settled already in proto-historical times (a burial site from over 3000 years ago, before the expansion of Etruscans). During the Roman Empire, villas and small villages scattered along the coast existed. In the books from this time (es. Vergil, Aeneid), the area is indicated as the place where homeric hero Aeneas landed with a few ships after the destruction of Troy. Indeed, in Roman times, malaria was diffused in this area, probably introduced from the nearby Pontine Marshes. With the crisis of the Roman Empire, the coastal plain was partly covered with stagnant, still water, and malaria spread over most of this territory, which was abandoned by the population. In the Middle Ages, the territory of Castelporziano was a forest used for the exploitation of wood, for hunting and for the breeding of the Italian buffalo. Only during the last centuries, the area became property of members of the Roman aristocracy, and a part of its surface was reclaimed and used as hunting grounds, for intensive breeding or cultivation. In fact, the name Castelporziano means "Castle of the wild boars" a clear allusion to the presence of these animals and hunting activity in the area. After the unity of Italy (1870), the area was bought by the Italian Government as a hunting 
estate for the royal family, and successively (after the proclamation of the Italian Republic in 1946) it became state property and was successively integrated with the contiguous area of Capocotta.

The use of Castelporziano as hunting grounds was maintained up to the 1970s, and later abandoned; meanwhile, also malaria was definitely eradicated. Around this time, the area began to be organised as a natural reserve: in fact, most of the surface is a well-preserved example of the pristine conditions of the Mediterranean coastal environment, with consistent elements of the wild fauna: only few comparable examples of coastal habitats of similar extension exist in the Mediterranean basin.

The total area of the Casteporziano Estate is indicated as Zona di Protezione Speciale (ZPS) according to DC 79/409 CEE; two biotopes (Farnete and Grotta di Piastra) are recognised as Siti di Interesse Comunitario (SIC) and Castelporziano belongs to the Network Natura 2000. It consists of 8 zones with integral protection and 11 zones indicated as "oriented reserves".

Since the 1980s, the activities for nature conservation in Castelporziano are promoted and planned by the Technical-Scientific Commission operating under the supervision of the Presidential Secretariat of the Republic. The Commission elaborates the programs of scientific research, organises the programs for forestry management of the woodland, controls the validation and publication of scientific results and is responsible for the conservation of wilderness conditions in general. For over two decades, as the President of the Commission, prof. G. T. Scarascia Mugnozza promoted and directed scientific research and conservation policy in Castelporziano (cf. the following article by E. Chiancone).

For these new tasks, a fruitful collaboration was started with several departments of the Rome University "La Sapienza" and Università della Tuscia in Viterbo, and successively also with the universities Roma 2 and Roma 3. In the Tenuta, the Observatory "Centre for the multidisciplinary Study of Mediterranean Coastal Ecosystems" is active. Scientific results are published in "Atti e Documenti dell' Accademia Nazionale delle Scienze detta dei XL"—of which 3 Series of volumes were published (including also a complete bibliography)—and in specialised international literature.

The objective of the present volume is to offer an approach to recent results in the study of the Castelporziano area and of the fallout of scientific research on nature conservation and on ecological education. Its task is in no way that of giving exhaustive general information in the form of a monograph on the study area. This is a first example of a publication dedicated to Castelporziano, composed only of papers in the style of modern international scientific literature, concise and submitted to peer review, a model for further investigations.

The volume is divided into 11 chapters.

1. Location, climate and soil various contributions to atmospheric circulation and the function of the forest as a sink for ozone, isoprenoid emissions, long-term monitoring of morpho-sedimentological and hydrological changes during a period of aridity, variations in salinity of the soil-water.

2. History a testimony (Pliny the Younger) of the conditions of this forest at the time of the Roman Empire, and history of the recent management.

3. Biodiversity and conservation Flora: bioindication based on morphological, anatomical and physiological traits of the Mediterranean evergreen flora.

4. Biodiversity and conservation Fauna: numerous articles on different faunal components: insects (several groups), microcrustaceans, reptiles, birds.

5. Climate change in the forest changes in soil humidity, the increasing aridity of the substrate over the last years and their consequences on the growth rate of the pine, and the significance of humus for the carbon sequestration of the forest ecosystem.

6. Forest ecology recent results of research on the humus component in the soil of the Mediterranean forest, definition of Amphimull, Dysmull and the flora-based Humus Functionality Index, impact of pollutants on forest vegetation.

7. Growth and reproduction of oaks and pine plantations presence of many oak species in the forest and variations in land use/land cover changes, problems in oak renovation and evaluation of the naturalness of forest composition using remote-sensing methods.

8. Large mammals populations studies on numerical fluctuations in the wild fauna of ungulates and genetics of the introduced herds of Maremmano cattle and Maremmano horse.

9. Bioindication contributions to biophysical and socioeconomic factors in Latium and to the variations of microarthropods in soil; bioindication is also largely used in articles of the previous chapters.

10. Human settlements several contributions to landscape dynamics in the urban area of Rome and the significance of an extended example of natural forest.

11. Nature conservation relicts of Laurisilva along the Tyrrhenian coast and their biogeographical significance. 